\title{
IMPLEMENTASI PROGRAM JALAN HIJAU UNTUK MENDUKUNG PELAKSANAAN KONSTRUKSI RENDAH KARBON
}

\author{
Wimpy Santosa \\ Ketua Unit Kerja Jurnal HPJI \\ Himpunan Pengembangan Jalan Indonesia \\ Jln. Dharmawangsa Raya No. 125 \\ Jakarta Selatan \\ Tlp. 021-7251864 \\ wimpy.santosa@gmail.com
}

\author{
Greece Maria Lawalata \\ Pusat Litbang Jalan dan Jembatan \\ Balitbang, Kementerian PUPR \\ Jln. A.H. Nasution 264 \\ Bandung \\ Tlp. 085624383222 \\ greece.maria@pusjatan.pu.go.id
}

\begin{abstract}
Negative impacts from the implementation of road construction, namely increasing carbon emissions or Greenhouse Gas Emissions, need to be taken into account, because it is very influential on climate change. Indonesia will experience significant losses due to climate change, because Indonesia is an island-shaped country. The longer dry season will increase the frequency of extreme weather, and heavy rains are increasingly likely to increase flooding. The Green Road Program is a program that has the potential to reduce carbon emissions from the implementation of road construction. Currently the Green Road Rating Program has been held in Indonesia for 3 years, from 2015 until 2017. By looking at the results obtained in other countries, the Green Road Program has the potential to reduce carbon emissions starting at around $28 \%$, for roads with rigid pavement, up to around $37 \%$, for roads with flexible pavements. When linked to the planned road construction in the 2014-2019 Directorate General of Highways Strategic Plan, which is 2,650 $\mathrm{km}$ of non-toll national roads and $1,000 \mathrm{~km}$ of toll roads, the implementation of the Green Road Program has the potential to reduce carbon emissions between 1.5 million tons and 2.0 million tons of $\mathrm{CO}_{2}$ equivalent.
\end{abstract}

Keywords: implementation of road construction, carbon emissions, green roads, green road ranking

\begin{abstract}
Abstrak
Dampak negatif yang berasal dari pelaksanaan konstruksi jalan, yaitu meningkatnya emisi karbon atau emisi Gas Rumah Kaca, perlu diperhitungkan, karena sangat berpengaruh terhadap perubahan iklim. Indonesia akan mengalami kerugian yang signifikan akibat perubahan iklim, karena Indonesia merupakan suatu negara yang berbentuk kepulauan. Musim kering yang semakin panjang akan meningkatkan frekuensi cuaca ekstrim, dan hujan lebat yang semakin sering berpeluang untuk meningkatkan terjadinya banjir. Program Jalan Hijau merupakan suatu program yang berpotensi untuk mengurangi emisi karbon yang berasal dari pelaksanaan konstruksi jalan. Saat ini Program Pemeringkatan Jalan Hijau telah diselenggarakan di Indonesia selama 3 tahun, yaitu pada tahun 2015 sampai dengan tahun 2017. Dengan melihat hasil yang diperoleh di negara lain, Program Jalan Hijau berpotensi mengurangi emisi karbon mulai dari sekitar 28\%, untuk jalan dengan perkerasan kaku, hingga sekitar 37\%, untuk jalan dengan perkerasan lentur. Bila dikaitkan dengan rencana pembangunan jalan yang terdapat pada Rencana Strategis Direktorat Jenderal Bina Marga 2014-2019, yaitu $2.650 \mathrm{~km}$ jalan nasional nontol dan $1.000 \mathrm{~km}$ jalan tol, implementasi Program Jalan Hijau berpotensi mengurangi emisi karbon antara 1,5 juta ton hingga 2,0 juta ton $\mathrm{CO}_{2}$ ekuivalen.
\end{abstract}

Kata-kata kunci: pelaksanaan konstruksi jalan, emisi karbon, jalan hijau, pemeringkatan jalan hijau

\section{PENDAHULUAN}

Salah satu dampak negatif pelaksanaan konstruksi infrastruktur jalan adalah dihasilkannya emisi karbon atau emisi Gas Rumah Kaca (GRK). Suatu studi di Korea 
menunjukkan bahwa untuk setiap meter pembangunan jembatan dihasilkan emisi sebanyak 120,1 ton $\mathrm{CO}_{2}$, diikuti oleh setiap meter pembangunan terowongan sebanyak 29,6 ton $\mathrm{CO}_{2}$, dan setiap meter jalan sebanyak 7,5 ton $\mathrm{CO}_{2}$, yang pada umumnya berasal dari konsumsi bahan utama konstruksi (Seo dan Kim, 2013). Sedangkan Greenroads Foundation (2010) menyatakan bahwa untuk membangun 1 mil jalan satu lajur diperlukan energi yang setara dengan energi yang dikonsumsi oleh 100 rumah tangga di Amerika selama 1 tahun. Untuk membangun 1 lajur jalan bebas hambatan sepanjang 1 mil, akan dihasilkan polusi yang setara dengan 1.200 ton $\mathrm{CO}_{2}$, yang hampir setara dengan total emisi 210 mobil penumpang dalam 1 tahun.

Pemeliharaan dan pembangunan jalan di Indonesia akan selalu meningkat di masa mendatang. Karena itu, dampak negatif kegiatan konstruksi jalan, yaitu meningkatnya emisi karbon atau emisi Gas Rumah Kaca, perlu dikurangi, karena sangat berpengaruh terhadap perubahan iklim. Pengurangan emisi ini diharapkan dapat mengurangi secara signifikan dampak negatif pekerjaan infrastruktur jalan tersebut.

Indonesia akan mengalami banyak kerugian yang signifikan akibat perubahan iklim karena Indonesia merupakan suatu negara yang berbentuk kepulauan. Musim kering yang semakin panjang akan meningkatkan frekuensi cuaca ekstrim, dan hujan lebat yang semakin sering berpeluang untuk meningkatkan terjadinya banjir.

Program jalan hijau merupakan suatu program yang telah diselenggarakan di Indonesia, yang diprakarsai oleh Pusat Penelitian dan Pengembangan Jalan dan Jembatan (Pusjatan), Badan Penelitian dan Pengembangan (Balitbang), Kementerian Pekerjaan Umum dan Perumahan Rakyat (PUPR). Program ini dimaksudkan untuk mendukung pelaksanaan pembangunan jalan yang sesuai dengan prinsip konstruksi berkelanjutan, yang terdapat dalam Peraturan Menteri Pekerjaan Umum dan Perumahan Rakyat Nomor 5 Tahun 2015, tentang Pedoman Umum Implementasi Konstruksi Berkelanjutan pada Penyelenggaraan Infrastruktur Bidang Pekerjaan Umum dan Permukiman.

Untuk mendukung implementasi Program Jalan Hijau, pada tahun 2015 Kepala Balitbang Kementerian PUPR menetapkan Tim Jalan Hijau, yang bertugas melakukan pembakuan sistem penilaian jalan hijau dan mempersiapkan strategi implementasinya, melalui Surat Keputusan Kepala Badan Penelitian dan Pengembangan No. 34/KPTS/2016, tanggal 18 April 2016, tentang Perubahan Kedua atas Keputusan Kepala Badan Penelitian dan Pengembangan No. 01/KPTS/KL/2015, tentang Pembentukan Tim Jalan Hijau Indonesia Tahun Anggaran 2015-2017.

Penerapan pemeringkatan jalan hijau pertama kali dilaksanakan pada tahun 2015 . Pada tahun 2016 dan tahun 2017 dilaksanakan kembali penerapan Sistem Pemeringkatan Jalan Hijau terhadap beberapa proyek pekerjaan jalan, baik proyek yang dilaksanakan oleh penyelenggara jalan pusat maupun yang dilaksanakan oleh penyelenggara jalan daerah. Walaupun demikian, jumlah proyek jalan yang disertakan untuk diperingkat sebagai jalan hijau masih sangat sedikit dan masih jauh dari harapan.

Pada makalah ini dilakukan kajian terhadap konsep penyelenggaraan jalan hijau serta proses pemeringkatan jalan hijau. Selain itu, dibahas pula potensi pengurangan karbon pada proyek konstruksi jalan yang menerapkan prinsip jalan hijau serta permasalahan yang terjadi pada proses pemeringkatan jalan hijau di Indonesia. 


\section{PEMERINGKATAN JALAN HIJAU}

Menurut Greenroads Foundation (2018), sistem peringkat jalan hijau merupakan suatu cara mudah untuk mengukur dan mengelola keberlanjutan suatu proyek infrastruktur transportasi, khususnya infrastruktur transportasi jalan. Sistem pemeringkatan tersebut dibuat sedemikian rupa sehingga menantang pihak pelaksana pembangunan jalan untuk dapat memenuhi dan bahkan melampaui ukuran kinerja pembangunan jalan, yang meliputi aspek-aspek lingkungan, sosial, dan ekonomi.

Di Indonesia, Pedoman Pemeringkatan Jalan Hijau disusun berdasarkan hasil-hasil penelitian yang dilakukan oleh Balai Sistem Teknik Lalu Lintas dan Lingkungan Jalan, Pusat Penelitian dan Pengembangan Jalan dan Jembatan. Pemeringkatan jalan hijau tersebut dilakukan pada tahap perancangan dan tahap pelaksanaan konstruksi suatu proyek jalan.

Pemeringkatan jalan hijau merupakan suatu upaya untuk mendorong implementasi konsep konstruksi berkelanjutan pada penyelenggaraan infrastruktur bidang pekerjaan umum dan permukiman. Implementasi konstruksi berkelanjutan tersebut mencakup konstruksi jalan, yang dilakukan pada tahap pemrograman, perancangan, pelaksanaan konstruksi, pemanfaatan, dan pembongkaran, untuk memastikan bahwa ketersediaan, keberlangsungan, dan keberlanjutan pemenuhan sumber daya dalam pembangunan infrastruktur dilakukan dengan mengacu dan memenuhi kriteria konstruksi berkelanjutan.

Tujuan dilaksanakan pemeringkatan jalan adalah untuk mengetahui jumlah kegiatan yang mengupayakan penerapan prinsip berkelanjutan pada konstruksi jalan. Upaya penerapan prinsip berkelanjutan tersebut mencakup: (1) perlindungan terhadap air, udara, dan tanah, (2) perlindungan mitigasi habitat, (3) penggunaan produk lokal yang ramah lingkungan, (4) penggunaan energi yang ramah lingkungan, serta (5) penyediaan fasilitas perlengkapan jalan yang berkeadilan terhadap pengguna kendaraan bermotor dan pengguna kendaraan tidak bermotor. Prinsip berkelanjutan dimuat dalam beberapa kriteria jalan hijau. Kriteria tersebut dikelompokkan dalam 5 kategori, yaitu: (1) konservasi lingkungan air, udara, dan alam, (2) transportasi dan masyarakat, (3) kegiatan konstruksi, (4) material dan sumber daya alam, serta (5) teknologi perkerasan.

Pemeringkatan jalan hijau dilakukan pada tahap perancangan dan pelaksanaan konstruksi. Proses pemeringkatan diawali dengan pendaftaran secara sukarela proyek jalan yang akan diperingkat, yang dilengkapi dengan pemenuhan berbagai persyaratan yang telah ditetapkan, yaitu memiliki dokumen Life Cycle Cost atau diwakili oleh Laporan Studi Kelayakan atau kajian ekonomi serta dokumen lingkungan, seperti Dokumen Amdal, Dokumen Upaya Pengelolaan Lingkungan Hidup, dan Upaya Pemantauan Lingkungan Hidup (UKL-UPL), Surat Pernyataan Pengelolaan Lingkungan Hidup (SPPLH), Dokumen Pengelolaan Lingkungan Hidup (DPLH), atau Dokumen Evaluasi Lingkungan Hidup (DELH), as built drawing, dan formulir pemeringkatan jalan hijau. Selanjutnya, dilakukan penilaian mandiri yang berisi penjelasan yang berkaitan dengan kategori dan kriteria jalan hijau disertai dengan bukti gambar atau foto proyek jalan yang didaftarkan. Penilaian mandiri ini selanjutnya akan divalidasi serta dievaluasi oleh Tim Jalan Hijau. Apabila jalan yang 
diusulkan memenuhi kriteria yang telah ditetapkan, jalan tersebut akan mendapat peringkat jalan hijau, yang ditetapkan dengan pemberian sertifikat dan label jalan hijau.

Pada saat ini terdapat 84 kriteria untuk pemeringkatan jalan hijau, yang dikelompokkan dalam 5 kategori, dan selanjutnya dipecah pada subkategori-subkategori, seperti terlihat pada Gambar 1 (Lawalata, 2019). Uraian setiap ketegori adalah sebagai berikut:

1) Kategori KL, atau konservasi lingkungan air, udara, dan alam, terdiri atas subkategori: (1) KL-1, pelatihan kesadaran lingkungan; (2) KL-2, mitigasi bencana; (3) KL-3, pengurangan polusi udara atau debu pada saat pelaksanaan konstruksi atau pascakonstruksi; (4) KL-4, sertifikat sistem manajemen lingkungan dan penerapan inovasi pelaksana pekerjaan; (5) KL-5, penanaman pohon dan jenis vegetasi lain; (6) KL-6, pelindungan dan penghindaran kehilangan habitat; (7) KL-7, penyediaan sistem drainase jalan, (8) KL-8, pembatasan penerangan jalan; dan (9) KL-9, pereduksi kebisingan.

2) Kategori TM, atau transportasi dan masyarakat, terdiri atas subkategori: (1) TM-1, penataan ornamen dan lanskap jalan; (2) TM-2, penyediaan fasilitas henti untuk menikmati pemandangan menarik; (3) TM-3, penyediaan akses dan fasilitas pengguna angkutan umum; (4) TM-4, perancangan geometrik dan fasilitas perlengkapan jalan untuk menekan penggunaan energi; (5) TM-5, pelaksanaan audit keselamatan jalan oleh pihak independen; (6) TM-6, penyediaan akses dan fasilitas pejalan kaki; (7) TM-7, pelibatan peran serta masyarakat dalam perencanaan; dan (8) TM-8, penyediaan akses dan fasilitas pesepeda.

3) Kategori AK, atau aktivitas konstruksi, terdiri atas subkategori: (1) AK-1, perencanaan kegiatan daur ulang sampah konstruksi dan sampah dari kantor atau base camp kontraktor; (2) AK-2, metode penggunaan peralatan atau armada pelaksanaan konstruksi dengan teknologi tertentu sehingga emisi dapat dikurangi; (3) AK-3, pemantauan atau pencatatan penggunaan air pada pelaksanaan konstruksi; (4) AK-4, penggunaan peralatan konstruksi yang memenuhi ambang batas emisi; (5) AK-5, pengurangan penggunaan bahan bakar fosil pada pelaksanaan konstruksi atau base camp kontraktor; (6) AK-6, pelaksanaan koordinasi tim perancang dan pelaksana konstruksi untuk mengefektifkan dan mengefisienkan waktu pelaksanaan konstruksi; (7) AK-7, kontraktor memiliki sertifikat Sistem Manajemen Mutu (SMM); AK-8, penjaminan mutu pelaksanaan konstruksi oleh kontraktor bahwa produk pelaksanaan konstruksi sesuai dengan mutu pada proses pelelangan; (9) AK-9, penggunaan energi terbarukan saat pelaksanaan konstruksi; dan (10) AK-10, menyiapkan dokumen untuk investasi atau aktivitas "pembelian karbon" terkait dengan upaya pengurangan gas rumah kaca atau emisi karbon.

4) Kategori MS, atau material dan sumber daya alam, terdiri atas subkategori: (1) MS-1, penggunaan material daur ulang pada proyek jalan, baik yang sedang dibangun atau pada jalan yang berbeda; (2) MS-2, penggunaan ulang material bongkaran (selain tanah) di lokasi setempat; (3) MS-3, penggunaan material lokal; (4) MS-4, penggunaan minimal 90\% material tanah galian untuk timbunan setempat; (5) MS-5, pemanfaatan material bongkaran di luar lokasi proyek; dan (6) MS-6, lampu penerangan jalan yang menggunakan sumber daya hemat energi. 
5) Kategori teknologi perkerasan, yang terdiri atas pilihan subkategori dalam perkerasan untuk badan jalan dan perkerasan untuk trotoar jalan. Subkategori perkerasan untuk badan jalan terdiri atas: (1) TPK-1, perancangan umur rencana perkerasan; (2) TPK-2, penggunaan campuran dingin untuk pekerasan lentur; (3) TPK-3, penggunaan perkerasan porus yang berfungsi untuk meresapkan dan mengalirkan air permukaan di perkerasan jalan yang dilengkapi dengan fasilitas saluran air keluar jika sudah melebihi kapasitas; (4) TPK-4, perancangan permukaan perkerasan yang dapat mengurangi kebisingan; dan (5) TPK-5, perancangan campuran beraspal hangat. Sedangkan subkategori pada perkerasan untuk trotoar jalan terdiri atas: (1) TPP-1, perancangan perkerasan pejalan kaki yang mempertahankan fungsi trotoar yang dimaksudkan untuk menekan biaya pemeliharaan jalan; (2) TPP-2, penggunaan material yang dibuat tanpa pemanasan; (3) TPP-3, perancangan permukaan perkerasan porus; (4) TPP-4, perancangan permukaan perkerasan yang kekesatannya memenuhi persyaratan untuk jalur pejalan kaki; dan (5) TPP-5, penggunaan material yang dibuat dengan pemanasan lebih rendah daripada temperatur standar.

Pada saat ini terdapat 4 peringkat jalan hijau yang diberikan kepada suatu proyek jalan yang diikutsertakan dalam pemeringkatan jalan hijau, yang dinyatakan dalam sejumlah bintang. Peringkat tersebut dapat dilihat pada Tabel 1.

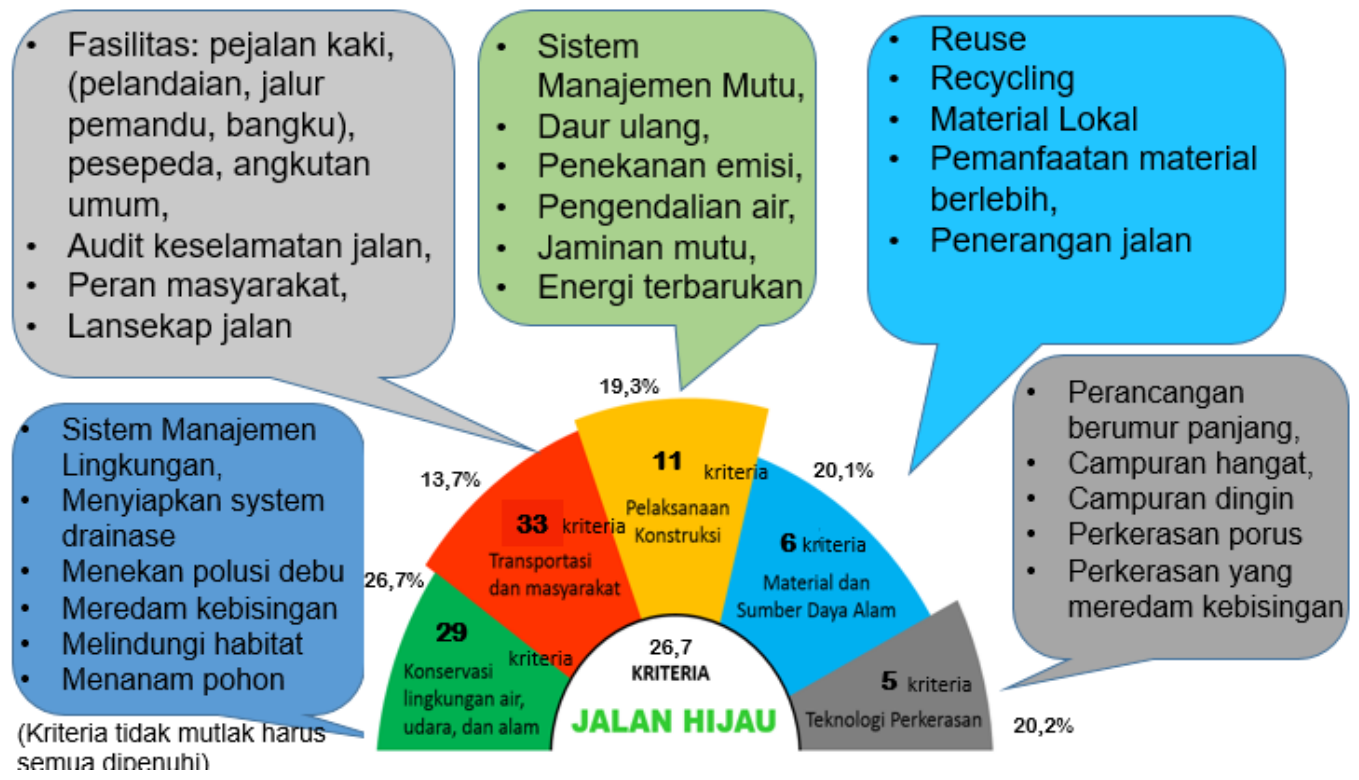

Gambar 1 Kategori dan Subkategori Pemeringkatan Jalan Hijau I (Lawalata, 2019)

Tabel 1 Peringkat Jalan Hijau

\begin{tabular}{cl}
\hline Jumlah Bintang & Kriteria Peringkat Jalan Hijau \\
\hline 4 & Nilai penerapan kriteria jalan hijau lebih besar daripada $45,00$. \\
3 & Nilai penerapan kriteria jalan hijau antara 20,01 dan $44,00$. \\
2 & $\begin{array}{l}\text { Nilai penerapan kriteria jalan hijau lebih kecil atau sama dengan } 20,00 . \\
\text { Jalan yang telah memenuhi persyaratan teknis jalan, memiliki analisis } \\
\text { life cycle cost, dan memiliki dokumen lingkungan. }\end{array}$ \\
\hline
\end{tabular}




\section{BEBERAPA HASIL PEMERINGKATAN JALAN HIJAU}

Pemeringkatan jalan hijau telah dilaksanakan untuk beberapa proyek jalan pada tahun 2015, 2016, dan 2017. Rincian proyek-proyek jalan yang mengikuti pemeringkatan jalan hijau pada kurun waktu tersebut dapat dilihat pada Tabel 2.

Tabel 2 Proyek Jalan yang Mengikuti Pemeringkatan Jalan Hijau

\begin{tabular}{|c|c|c|}
\hline Proyek Jalan dan Pelaksana & Gambaran Lingkup Pekerjaan & Guna Lahan \\
\hline \multicolumn{3}{|l|}{ Tahun 2015} \\
\hline $\begin{array}{l}\text { 1) Jalan dan Jembatan Kelok Sembilan- } \\
\text { Padang, BBJN }\end{array}$ & $\begin{array}{l}\text { Jalan, jembatan, akses ornamen jalan, } \\
\text { penerangan jalan umum }\end{array}$ & $\begin{array}{l}\text { Hutan } \\
\text { lindung }\end{array}$ \\
\hline $\begin{array}{l}\text { 2) Jalan Tol Bali Mandara, } \\
\text { PT Jasamarga Bali Tol }\end{array}$ & $\begin{array}{l}\text { Jalan, jembatan, ornamen jalan, akses sepeda } \\
\text { motor, penerangan jalan umum }\end{array}$ & Pantai \\
\hline $\begin{array}{l}\text { 3) Underpass Dewa Ruci-Denpasar, } \\
\text { BBPJN }\end{array}$ & $\begin{array}{l}\text { Underpass, jalan, saluran drainase, trotoar, } \\
\text { taman, pohon, penerangan jalan umum }\end{array}$ & Pemukiman \\
\hline 4) Fly Over Bukit Tinggi, BBPJN & $\begin{array}{l}\text { Fly over, jalan, saluran drainase, trotoar, } \\
\text { penerangan jalan umum }\end{array}$ & $\begin{array}{l}\text { Pemukiman, } \\
\text { pasar }\end{array}$ \\
\hline \multicolumn{3}{|l|}{ Tahun 2016} \\
\hline $\begin{array}{l}\text { Pembangunan Saluran Drainase dan } \\
\text { Trotoar Jalan Braga, Pemerintah } \\
\text { Kota Bandung }\end{array}$ & $\begin{array}{l}\text { Saluran drainase, trotoar, ornamen jalan, } \\
\text { penerangan jalan umum, fasilitas pejalan kaki }\end{array}$ & $\begin{array}{l}\text { Pertokoan, } \\
\text { kawasan } \\
\text { heritage }\end{array}$ \\
\hline $\begin{array}{l}\text { Pembangunan Jalan Gerung (Patung } \\
\text { Sapi) Mataram, BPJN }\end{array}$ & $\begin{array}{l}\text { Jalan, saluran drainase, trotoar (sebagian), } \\
\text { pohon, penerangan jalan umum }\end{array}$ & $\begin{array}{l}\text { Sawah, } \\
\text { pemukiman }\end{array}$ \\
\hline $\begin{array}{l}\text { Pembangunan Jalan Tol Semarang-- } \\
\text { Solo Tahap I, Ruas Semarang-- } \\
\text { Bawen }\end{array}$ & $\begin{array}{l}\text { Jalan, jembatan, saluran drainase, ornamen } \\
\text { jalan, penerangan jalan umum }\end{array}$ & $\begin{array}{l}\text { Hutan, } \\
\text { ladang, } \\
\text { pemukiman }\end{array}$ \\
\hline $\begin{array}{l}\text { Jalan Tembus Jln. Kartini-Jln. } \\
\text { Gajah, Pemerintah Kota Semarang }\end{array}$ & $\begin{array}{l}\text { Jalan, jembatan, akses ke jalan lingkungan, } \\
\text { saluran drainase, trotoar, lajur sepeda berbagi, } \\
\text { ornamen jalan, penerangan jalan umum }\end{array}$ & $\begin{array}{l}\text { Pemukiman, } \\
\text { ladang }\end{array}$ \\
\hline $\begin{array}{l}\text { Jalan Karangandong-Kesamben } \\
\text { Kulon Kabupaten Gresik-Pemerintah } \\
\text { Kabupaten Gresik }\end{array}$ & $\begin{array}{l}\text { Jalan, saluran drainase, penerangan jalan } \\
\text { umum }\end{array}$ & $\begin{array}{l}\text { Pemukiman, } \\
\text { ladang }\end{array}$ \\
\hline $\begin{array}{l}\text { Pembangunan Jembatan di Sekitar } \\
\text { Pintu Tol Bekasi Timur-Pemerintah } \\
\text { Kota Bekasi }\end{array}$ & $\begin{array}{l}\text { Jalan, jembatan, akses ke jalan lingkungan, } \\
\text { saluran drainase, trotoar, lajur sepeda berbagi, } \\
\text { ornamen jalan, penerangan jalan umum }\end{array}$ & $\begin{array}{l}\text { Pemukiman, } \\
\text { sungai }\end{array}$ \\
\hline \multicolumn{3}{|l|}{ Tahun 2017} \\
\hline 1) Jembatan Tayan, BBPJN & $\begin{array}{l}\text { Jalan, jembatan, akses, ornamen jalan, } \\
\text { penerangan jalan umum }\end{array}$ & Perkebunan \\
\hline $\begin{array}{l}\text { 2) Jalan dan Jembatan Ibun-Kamojang, } \\
\text { Pemkab Bandung }\end{array}$ & Jalan, jembatan, akses, ornamen jalan & Hutan \\
\hline
\end{tabular}

Sumber: Tim Jalan Hijau Indonesia $(2015,2016,2017)$

Hasil penilaian terhadap proyek-proyek jalan yang didaftarkan untuk mengikuti pemeringkatan jalan hijau pada periode tahun 2015-2017 dapat dilihat pada Tabel 3. Terdapat 3 proyek jalan yang mendapat Peringkat Bintang 4, yaitu Proyek Jalan dan Jembatan Kelok Sembilan, Proyek Jalan Tol Bali Mandara, dan Proyek Underpass Dewa Ruci, Bali. Sisanya mendapat Peringkat Bintang 3.

\section{POTENSI PENGURANGAN KARBON DAN KENDALA}

Pengalaman di luar negeri menunjukkan bahwa pembangunan infrastruktur jalan memberikan dampak negatif dengan dihasilkannya emisi karbon atau Gas Rumah Kaca 
(GRK). Program jalan hijau berpotensi untuk mengurangi emisi karbon yang berasal dari pembangunan atau proyek-proyek jalan di Indonesia.

Tabel 3 Hasil Penilaian Proyek Jalan

\begin{tabular}{|c|c|c|c|c|c|c|c|c|}
\hline \multirow[b]{2}{*}{ No. } & \multirow[b]{2}{*}{ Tahun } & \multirow[b]{2}{*}{ Nama Proyek } & \multicolumn{6}{|c|}{ Nilai Setiap Kategori } \\
\hline & & & Lingkungan & $\begin{array}{l}\text { Transportasi } \\
\text { dan } \\
\text { Masyarakat }\end{array}$ & $\begin{array}{l}\text { Aktivitas } \\
\text { Konstruksi }\end{array}$ & Energi & $\begin{array}{l}\text { Teknologi } \\
\text { Perkerasan } \\
\text { Jalan }\end{array}$ & Total \\
\hline 1. & 2015 & $\begin{array}{l}\text { Jalan dan Jembatan Kelok } \\
\text { Sembilan }\end{array}$ & 18,8 & 6,0 & 7,6 & 8,1 & 5,9 & 46,4 \\
\hline 2. & 2015 & Jalan Tol Bali Mandara & 20,3 & 7,9 & 9,5 & 1,7 & 5,9 & 45,3 \\
\hline 3. & 2015 & $\begin{array}{l}\text { Underpass Dewa Ruci, } \\
\text { Bali }\end{array}$ & 17,3 & 8,8 & 10,8 & 5,6 & 5,9 & 48,4 \\
\hline 4. & 2015 & Fly Over Bukit Tinggi & 11,0 & 6,4 & 9,7 & 5,1 & 5,9 & 38,0 \\
\hline 5. & 2016 & $\begin{array}{l}\text { Pembangunan Saluran } \\
\text { Drainase dan Trotoar } \\
\text { Jalan Braga-Bandung }\end{array}$ & 10,32 & 6,97 & 5,26 & 6,24 & 5,88 & 34,67 \\
\hline 6. & 2016 & $\begin{array}{l}\text { Pembangunan Jalan } \\
\text { Gerung (Patung Sapi) } \\
\text { Mataram }\end{array}$ & 9,11 & 4,26 & 7,25 & 6,62 & 5,88 & 33,12 \\
\hline 7. & 2016 & $\begin{array}{l}\text { Pembangunan Jalan Tol } \\
\text { Semarang-Solo Tahap I } \\
\text { Ruas Semarang-Bawen }\end{array}$ & 13,99 & 8,18 & 10,58 & 6,47 & 3,29 & 42,51 \\
\hline 8. & 2016 & $\begin{array}{l}\text { Jalan Tembus Jln. } \\
\text { Kartini-Jln. Gajah, Kota } \\
\text { Semarang }\end{array}$ & 10,34 & 5,01 & 14,80 & 9,82 & 4,04 & 44,01 \\
\hline 9. & 2016 & $\begin{array}{l}\text { Pembangunan Jembatan } \\
\text { di Sekitar Pintu Tol } \\
\text { Bekasi Timur }\end{array}$ & 12,81 & 7,17 & 8,69 & 8,25 & 3,29 & 40,21 \\
\hline 10. & 2016 & $\begin{array}{l}\text { Jalan Karangandong- } \\
\text { Kesamben Kulon } \\
\text { Kabupaten Gresik }\end{array}$ & 12,02 & 5,36 & 11,63 & 14,73 & 0 & 43,74 \\
\hline 11. & 2017 & $\begin{array}{l}\text { Jalan dan Jembatan } \\
\text { Tayan, BBPJN }\end{array}$ & 10,04 & 6,32 & 5,29 & 9,77 & 5,88 & 37,30 \\
\hline 12. & 2017 & $\begin{array}{l}\text { Jalan dan Jembatan Ibun } \\
\text { Kamojang, Kabupaten } \\
\text { Bandung }\end{array}$ & 13,99 & 3,37 & 7,57 & 4,61 & 5,88 & 35,42 \\
\hline
\end{tabular}

Sumber: Tim Jalan Hijau Indonesia (2015, 2016, 2017)

Saat ini, total emisi GRK untuk infrastruktur jalan di Belanda mencapai 2.200 kiloton $\mathrm{CO}_{2}$ ekuivalen per tahun. Hasil penelitian di negara ini menunjukkan bahwa teknologi yang ramah lingkungan, yang merupakan kombinasi antara bahan dan teknologi inovatif, dapat mengurangi emisi karbon yang berasal dari proses-proses konstruksi, pemeliharaan, serta daur ulang hingga 30\%, atau setara dengan 660 kiloton $\mathrm{CO}_{2}$ ekuivalen per tahun. Inovasi teknologi yang digunakan meliputi perawatan yang dapat meningkatkan umur bahan pengikat di perkerasan beraspal, proses produksi campuran beraspal dengan temperatur rendah, penggunaan material daur ulang, serta penggunaan lampu penerangan jalan yang menggunakan sistem Light Emitting Diode (LED) atau menggunakan energi terbarukan. Pengalaman di Belanda juga menunjukkan bahwa emisi karbon yang terkait dengan jalan beraspal, baik di jaringan jalan primer maupun di jaringan jalan sekunder, dapat dikurangi sekitar $37 \%$ bila menggunakan teknologi yang ramah lingkungan, sementara pengurangan yang lebih kecil, yaitu sekitar 28\%, dapat dicapai untuk jalan yang menggunakan perkerasan kaku. 
Suatu studi yang dilakukan oleh World Bank (2010) menunjukkan bahwa pekerjaan perkerasan dan pekerjaan struktur pada suatu pembangunan jalan menghasilkan emisi GRK yang terbesar. Konstruksi jalan bebas hambatan (expressway) menghasilkan emisi GRK yang paling besar dibandingkan dengan jenis-jenis jalan yang lain. Selain itu, pembangunan jalan nasional memberikan emisi GRK lebih besar daripada pembangunan jalan provinsi (lihat Tabel 4).

Tabel 4 Rata-Rata Emisi GRK pada Pekerjaan Konstruksi Jalan (World Bank, 2010)

\begin{tabular}{lccc}
\hline $\begin{array}{c}\text { Emisi Per km } \\
\text { (Ton } \mathrm{CO}_{2} \text { Ekuivalen) }\end{array}$ & Jalan Bebas Hambatan & Jalan Nasional & Jalan Provinsi \\
\hline Pekerjaan Tanah & 161,40 & 15,89 & 12,00 \\
Perkerasan & 1333,86 & 424,66 & 157,30 \\
Gorong-Gorong & 238,48 & 51,45 & 16,69 \\
Struktur & 1067,99 & 119,39 & 20,57 \\
Perlengkapan Jalan & 432,40 & 182,42 & 0,00 \\
\hline Total & 3234,13 & 793,81 & 206,56 \\
\hline
\end{tabular}

Dalam Rencana Strategis Direktorat Jenderal Bina Marga 2014-2019 disebutkan bahwa pada kurun waktu tersebut pemerintah akan membangun jalan nasional sepanjang $2.650 \mathrm{~km}$ dan membangun jalan tol sepanjang $1.000 \mathrm{~km}$ (Direktorat Jenderal Bina Marga, 2014). Hal ini berarti pada periode tersebut terjadi emisi GRK sekitar 3.234 .130 ton $\mathrm{CO}_{2}$ ekuivalen yang berasal dari pembangunan jalan tol (jalan bebas hambatan) dan sekitar 2.103.596,5 ton $\mathrm{CO}_{2}$ ekuivalen yang berasal dari pembangunan jalan nasional nontol. Bila digunakan hasil kajian di Belanda, potensi pengurangan emisi GRK pembangunan jalan nasional (tol dan nontol) di Indonesia selama 5 tahun dapat mencapai antara 1,5 juta ton hingga 2,0 juta ton $\mathrm{CO}_{2}$ ekuivalen.

Dari hasil pelaksanaan pemeringkatan jalan hijau diketahui bahwa tidak semua kategori diterapkan di semua proyek yang diusulkan untuk diperingkat. Kategori dengan jumlah subkategori yang diterapkan paling sedikit adalah Kategori Teknologi Perkerasan untuk lalu lintas kendaraan dan/atau lalu lintas pejalan kaki, yang meliputi teknologi yang dapat menekan penggunaan energi dan teknologi yang ramah lingkungan. Hasil evaluasi menunjukkan bahwa penyelenggara jalan enggan untuk menerapkan teknologi baru karena memerlukan sumber daya manusia yang mampu untuk melaksanakan dan mampu memonitor pelaksanaannya (Lawalata, 2019).

Kategori lain yang jumlah subkategorinya juga sedikit diterapkan adalah Kategori Material dan Sumber Daya Alam, yang meliputi penggunaan ulang material bongkaran, seperti perkerasan jalan atau material lainnya, penggunaan material lokal, dan penggunaan sumber daya alam yang terbarukan. Pelaksanaan subkategori ini umumnya memerlukan dana yang besar sebagai modal. Untuk menerapkan subkategori dalam kategori ini dibutuhkan teknologi yang mendukung, sehingga biaya pengadaan dan biaya pelaksanaan dapat diminimalkan.

Dibandingkan dengan pembangunan jalan konvensional, pembangunan jalan hijau agak berbeda karena terdapat perbedaan konsep, fundamental, karakteristik, dan teknologi yang digunakan. Hal ini yang tampaknya menjadi kendala dalam pelaksanaan pembangunan 
jalan hijau. Karena itu, para pemangku kepentingan pembangunan jalan harus mengatasi berbagai tantangan yang ada agar tujuan pelaksanaan pembangunan proyek jalan hijau dapat dicapai. Kendala yang ada dapat terkait dengan hukum dan peraturan, ketentuan-ketentuan teknis dan fisik, keuangan, serta budaya yang didasarkan pada perspektif pemangku kepentingan.

\section{KESIMPULAN}

Kajian terhadap konsep penyelenggaraan jalan hijau serta proses pemeringkatan jalan hijau di Indonesia dibahas pada makalah ini. Penyelenggaraan jalan hijau tersebut dimaksudkan untuk mendukung pelaksanaan konstruksi rendah karbon, khususnya di bidang infrastruktur jalan. Terdapat potensi untuk mengurangi karbon pada proyek-proyek konstruksi jalan di Indonesia bila prinsip-prinsip jalan hijau diterapkan, walaupun hal ini masih menghadapi kendala di lapangan.

Pemeringkatan jalan hijau telah dilaksanakan di Indonesia pada tahun 2015, tahun 2016, dan tahun 2017. Proyek-proyek jalan yang diusulkan untuk diperingkat memang relatif masih sedikit, karena keikutsertaan suatu proyek jalan dalam pemeringkatan jalan hijau ini bersifat sukarela. Dari 12 proyek yang diperingkat, 3 di antaranya mendapat peringkat Bintang 4, sedangkan yang lain mendapat peringkat Bintang 3.

Keikutsertaan suatu proyek jalan dalam pemeringkatan jalan hijau perlu untuk selalu didorong agar jumlah proyek jalan yang diikutsertakan dalam pemeringkatan jalan hijau dapat lebih banyak, karena program jalan hijau ini mendukung pelaksanaan konstruksi, khususnya konstruksi jalan yang rendah karbon.

Rencana Direktorat Jenderal Bina Marga 2014-2019 mencantumkan rencana pembangunan jalan nasional nontol sepanjang $2.650 \mathrm{~km}$ dan jalan tol sepanjang $1.000 \mathrm{~km}$. Pembangunan jalan tersebut berpotensi menghasilkan emisi GRK sebanyak 5.337.726,5 ton $\mathrm{CO}_{2}$ ekuivalen. Bila digunakan pengalaman mengurangi emisi GRK di Belanda, potensi pengurangan emisi GRK yang berasal dari pembangunan jalan nasional (tol dan nontol) yang terdapat di Renstra Direktorat Jenderal Bina Marga 2014-2019 dapat mencapai antara 1,5 juta ton hingga 2,0 juta ton $\mathrm{CO}_{2}$ ekuivalen.

\section{CATATAN}

Versi awal makalah ini telah dipresentasikan oleh Penulis (mewakili Himpunan Pengembangan Jalan Indonesia) pada acara Pekan Sumber Daya Manusia Ahli Jasa Konstruksi, dengan Topik Peningkatan Kompetensi SDM Teknik Jalan Menyongsong Pembangunan Rendah Karbon. Acara tersebut diselenggarakan oleh Lembaga Pengembangan Jasa Konstruksi, bertempat di Indonesia Convention Exhibition, BSD City, pada tanggal 22 Maret 2019. 


\section{DAFTAR PUSTAKA}

Badan Penelitian dan Pengembangan. 2016. Keputusan Kepala Badan Penelitian dan Pengembangan Nomor 34/KPTS/2016, tanggal 18 April 2016, tentang Perubahan Kedua atas Keputusan Kepala Badan Penelitian dan Pengembangan Nomor 01/KPTS/KL/2015, tentang Pembentukan Tim Jalan Hijau Indonesia Tahun Anggaran 2015-2017. Kementerian Pekerjaan Umum dan Perumahan Rakyat. Jakarta.

Direktorat Jenderal Bina Marga. 2014. Rencana Strategis Direktorat Jenderal Bina Marga 2014-2019. Kementerian Pekerjaan Umum dan Perumahan Rakyat. Jakarta.

Greenroads Foundation. 2010. Why Green Transportation Matters. Redmond, WA.

Greenroads Foundation. 2018. Greenroads Rating System. Redmond, WA.

Kementerian Pekerjaan Umum dan Perumahan Rakyat. 2015. Peraturan Menteri PUPR No. 05/PRT/M/2015 tentang Pedoman Umum Implementasi Konstruksi Berkelanjutan pada Penyelenggaraan Infrastruktur Bidang Pekerjaan Umum dan Permukiman. Jakarta.

Lawalata, G.M. 2019. Pemeringkatan Jalan Hijau untuk Mendukung Implementasi Program Konstruksi Jalan Berkelanjutan. Jurnal HPJI, 5 (1): 21-30.

Seo, Y. dan Kim, S.M. 2013. Estimation of Materials-Induced $\mathrm{CO}_{2}$ Emission from Road Construction in Korea. Elsevier, Renewable and Sustainable Energy Reviews (26): 625-631.

Tim Jalan Hijau Indonesia. 2015. Laporan Penyelenggaraan Pemeringkatan Jalan Hijau. Badan Penelitian dan Pengembangan, Kementerian Pekerjaan Umum dan Perumahan Rakyat. Jakarta.

Tim Jalan Hijau Indonesia. 2016. Laporan Penyelenggaraan Pemeringkatan Jalan Hijau. Badan Penelitian dan Pengembangan, Kementerian Pekerjaan Umum dan Perumahan Rakyat. Jakarta.

Tim Jalan Hijau Indonesia. 2017. Laporan Penyelenggaraan Pemeringkatan Jalan Hijau. Badan Penelitian dan Pengembangan, Kementerian Pekerjaan Umum dan Perumahan Rakyat. Jakarta.

World Bank. 2010. Greenhouse Gas Emissions Mitigation in Road Construction and Rehabilitation: A Toolkit for Developing Countries. Washington, DC. 